\title{
The Ghostly Workings of Danish Accountability Policies
}

\author{
Pors, Justine Grønbæk
}

Document Version

Accepted author manuscript

Published in:

Journal of Education Policy

DOI:

10.1080/02680939.2016.1148781

Publication date:

2016

License

Unspecified

Citation for published version (APA):

Pors, J. G. (2016). The Ghostly Workings of Danish Accountability Policies. Journal of Education Policy, 31(4), 466-481. https://doi.org/10.1080/02680939.2016.1148781

Link to publication in CBS Research Portal

\section{General rights}

Copyright and moral rights for the publications made accessible in the public portal are retained by the authors and/or other copyright owners and it is a condition of accessing publications that users recognise and abide by the legal requirements associated with these rights.

Take down policy

If you believe that this document breaches copyright please contact us (research.lib@cbs.dk) providing details, and we will remove access to the work immediately and investigate your claim. 


\section{The Ghostly Workings of Danish Accountability Policies Justine Granbæk Pors \\ Journal article (Post print version)}

This is an Accepted Manuscript of an article published by Taylor \& Francis in Journal of Education Policy on 24 Feb 2016, available online: http://www.tandfonline.com//10.1080/02680939.2016.1148781

Cite: The Ghostly Workings of Danish Accountability Policies. / Pors, Justine Granbæk. In: Journal of Education Policy, Vol. 31, No. 4, 2016, p. 466-481.

Uploaded to Research@CBS: September 2016 


\section{The Ghostly Workings of Danish Accountability Policies}

\section{Justine Grønbæk Pors}

Department of Management, Politics and Philosophy, Copenhagen Business School, Copenhagen, Denmark

Adress: Porcelænshaven 18a, 2000 Frederiksberg C, Denmark

Email: jgp.mpp@cbs.dk.

Justine Grønbæk Pors is an assistant professor in welfare management and educational policy at the Department of Management Politics and Philosophy at Copenhagen Business School. Her research centres on different forms of policy innovations that put at stake our welfare society as we know it. Her research interests include affective effects of policy initiatives, historical development of expectations to professionals and local managers as well as the everyday life in welfare organisations. 


\title{
The Ghostly Workings of Danish Accountability Policies
}

\begin{abstract}
This article proposes a framework for thinking about the ghostly, thus arguing that policy can be understood as a landscape of intersecting and colliding temporalities from which arouse curious workings of barely-there forces, spooky energies and vibrating saturations of affective ambivalences. I present an empirical study of a policy agenda of introducing an assessment culture and improving the management of the Danish public school. I explore how all the routines and habits deemed out-dated and sought annihilated by a new policy paradigm continue to haunt head teachers as seething presences of lurking resistance towards the policy aims as well as insidious doubts.

Thinking about the ghostly contributes to studies of education policy by locating the reality of power in the mundane everyday doings and experiences of educational practitioners and insisting on the very tangled way people sense and intuit the complexities of contemporary forms of power.
\end{abstract}

Keywords: embedded policy; head teachers; accountability; everyday life; scholarly imagination

\section{Introduction}

For many years, policy sociologists have understood policy as something, which is not simply implemented, but rather explored policy as a bricolage of ideas, discourses and text, which are taken up in specific sites in particular ways (i.e. Ball 2006). Especially with regards to the emergence of an international policy space and global mechanisms such as governing by comparison (Lawn and Grek 2012; Grek 2009) and the importance of understanding how these travel, educational scholars have developed concepts such as embedded policy. Ozga and Jones $(2006,1)$ have defined embedded policy as policy that is 'mediated by local contextual factors that may translate policy to reflect local priorities and meanings.' Ozga, Seddon, and Popkewitz $(2006,8)$ have proposed that such embeddedness is recognised through the distinctive features of local traditions, ideologies, forms of organisation, ways of working and patterns of social movement. Similarly, Lingard, Martino, and Rezai-Rashti (2013) have argued for a need of 'vernacular versions' of global policy discourses thereby drawing attention to policy as hybrid manifestations that are a melange of local histories, cultures and politics. Ball, Maguire, and Braun (2012) have proposed an attention to context and enactment of policy and suggested a framework for studying the local multiple processes of translations in and through talk, school plans, meetings, classroom lessons, breaks and school websites. Thus, in recent years, emphasis has been placed on policy 
as processes of re-articulations and re-writings in a myriad of local settings all of which have their own ongoing tangle of histories, competing narratives, habits, teleologies and actors (Thomson, Hall, and Jones 2010, 639). This article continues this work by proposing a framework for thinking about the ghostly as a way to explore how policy changes make themselves felt in the everyday life of educational practitioners. Thinking about the ghostly is one way to highlight the uneasy intertwinements of political visions of better performance and local professional traditions. It draws attention to the seething presences of what has or is about to be lost, and, ultimately, teaches us something about the forces that make local traditions, values and histories disposable in the first place.

Curiously, since derridean deconstruction has had its hey-days in studies of education policy, the possibility that ghosts and ghostly matters are an inherent and inescapable part of everyday enactments of education policy has largely been ignored (see however, Kenway 2008; Lawn and Furlong 2009; Kenway, Bullen, Fahey, with Robb 2006). In human geography, cultural theory and sociology, ghosts and hauntological workings have been taken much more seriously (Blackman 2008; Maddern and Adey 2008; McCormack 2010; Hetherington 2004; Maddern 2008; Holloway 2006; Wylie 2007), and analytical attention to ghostly matters have produced apposite and stunning insights into what urban space is and how it affects us (Pile 2005; Edensor 2008, 2001), what it means to live in a dictatorship (Gordon 2008), how colonial pasts shape present day political practices (Coddington 2011), or how war and violence linger in humans and culture across generations (Cho 2008, 2007).

In this article, I present a framework for thinking about the ghostly apt to capture tensions between past, present and future in everyday experiences of policy changes. I re-tune Derrida's hauntology (Derrida 1994, 1999) to inquire into the affective intensities and uncanny atmospheres of everyday life in educational organisations. Like other social sciences, education studies need scholarly imagination and ways of tuning into the 'immense forces of atmosphere' concealed in everyday things (Benjamin 1987, 182). To draw attention to the ghostly is one way of insisting on the fact that educational policy is as intriguing, enchanted and full of shadows or other creatures escaping current regimes of knowledge as other social phenomena. Throughout the following pages, I propose that understanding educational policy is also a matter of paying attention to the work of hidden, sometimes even unspeakable forces and occurrences that may be little more than a trace or an elusively felt presence of 
something that should no longer be there, but yet is capable of affecting educational practitioners.

Empirically, I study the ghostly workings of political attempts to improve the Danish public schools by introducing a so-called assessment culture and by strengthening school management. In Denmark, as in many other countries, poor results in the PISA assessments caused shock waves in the political system and in the broader public (Staunæs and Pors 2015; Lingard and Sellar 2013; Sellar and Lingard 2013; Grek 2009). Two explanations for the poor results were given: A lack of proper assessments systems in the Danish education system (OECD 2004, 129) and weak and coincidental management in the public schools (the Danish Ministry of Education 2007, 83; the Danish Institute of Evaluation 2004, 2006; OECD 2008). As a response to these issues, the association of local Governments, Local Government Denmark (LGDK) launched a policy initiative entitled, A Culture of Evaluation - a New Danish School Tradition. In this article, with a point of departure in an ethnographic study of a large Danish municipality, I pursue two questions: 1) How do attempts to improve the Danish public school by strengthening management and implementing a new assessment culture conjure up fears of ghosts? 2) How do head teachers in the studied municipality try to make sense of and relate to the hidden forces and seething presences they experience their schools haunted by? I will show how this particular policy initiative conjure up lively, disturbing imaginings of how unspoken and unconscious habits of teachers rule the school and make it a cumbersome and dangerous institution to manage. Although the policy initiative attempts to make head teachers step into an unambiguous role as managers and demonstrate responsibility and accountability in relation to municipal policies (LGDK 2005a, 2, 2010a, 2008a, 2008b), the actions deemed outdated and inappropriate by these initiatives continue to haunt them as the spooky feeling that policy failures lurks in every corner of their schools.

Political initiatives similar to the one I study have been labelled neo-liberal and depicted as a performance economy of standardization, accountability and colonization of professional values (Webb 2005; Ball 2003; Walsh 2006; Williams and Ryan 2000; Clatter 2002; Weiner 2002; McGhee and Nelson 2005; Wilson, Croxson, and Atkinson 2006; Webb, Vulliamy, Sarja, and Hamalainen 2006). While I do not question that the agendas I study are indeed all that, by approaching the empirical data as a case of haunting, I am less interested in giving the forms of power at stake a general name, than 
in insisting on the very tangled way people sense, intuit, and experience the complexities of contemporary forms of government. The point I try to push is that the sensuous, oblique and uncanny experiences of our everyday organizational lives have everything to do with the character of power itself (Gordon 2008). My interest in the ghostly forms part of current attempts of educational scholars to account for the role of emotions and affects in policy, particularly in times of political anxiety to compete successfully in the global knowledge economy (Coffield 2012, 132; Blackmore 2010, 2011; Staunæs 2011; Staunæs \& Juelskjær 2015; Staunæs and Pors 2015). Moreover, it is connected to the efforts to pursue how education policy is experienced in everyday life (i.e. Thomson, Hall, and Jones 2010). My curiosity for the ghostly is not about exploring marginal or interstitial sites or spaces associated with spectacular or violent events (as i.e. Dudley 2006). Instead, I will interrogate how ghostly presences make themselves felt in mundane settings, quotidian practices, ordinary policy initiatives and conventional conversations.

In the following, I begin by sketching the contours of a framework for thinking about the ghostly. I take a point of departure in Derrida, but propose that we move beyond thinking about the ghostly in linguistic terms as corrupting and contaminating deferrals lurking in unstable links between signifier and signified. Second, I discuss my methodological strategy for pursuing ghostly workings. Drawing on the ethnographic concept of shadowing, in education studies developed by Wolcott (2003), I present how I have strived to shadow the shadows in the studied setting. Third, I analyse the ghostly workings of the political ambitions of implementing new assessment systems and generating better management in the Danish public school. I show how policy initiatives do not only convey the cheerful message of a modernized and better performing public school, but also diffuse a fear that schools are ruled by obstinate and autonomous habits of teachers. Fourth, I bring the reader to a specific event in which head teachers share their experiences of the difficulties of implementing the new accountability policies. I show how head teachers struggle to relate to seething presences of former routines and traditions whose power over the school seems to come from the fact that their ontological existence is unclear.

\section{Towards a framework for thinking about the ghostly}


A conceptual framework for thinking about the ghostly begins with a dismissal of the idea that time is linear. Indeed, the ghostly is a collapse of our experience of linear time (Edensor 2001, 42; Maddern 2008), as in Derrida's description (1994), where the spectre's presence reveals that there is neither a beginning nor an end to history: how Marxism endures despite the supposed triumph of capital liberal democracy. The spectre has to do with the ways in which the forgotten, overlooked, neglected and rubbished come back to demand recognition (Hetherington 2004). As Miles (2001, 110) has suggested, haunting is a narrative gone wrong, 'a story thrown out of the door reappearing ghostlike at the window.' Thinking about the ghostly is a way to draw attention to the fact that policy narratives of change are not only forceful in their replacement of certain inadequate pasts with glossy futures, but also often fragile and precarious: How such narratives rather than produce linear progress are more likely to produce 'endings that are not over' (Gordon 2008, 139) and temporal collages consisting of a host of intersecting temporalities colliding and merging in a landscape of juxtaposed asynchronous moments. Thinking about the ghostly can attune us to how elements that become homeless when new policy narratives are introduced do not willingly disappear. How the apparent order of organizational presences is 'everywhere punched and torn open by ellipses, drifts and leaks of meaning' (de Certeau 1984, 107) and how this contributes to other, darker, and more complex narratives that haunt educational spaces like superfluous or additional inhabitants.

As many other scholarly ghost stories, this one is indebted to Derrida for whom the ghostly is a breakdown of distinctions between absent and present: 'the experience of the non- present, of the non-living present in the living present, of that which lives on' (Derrida 1999, 254). Derrida writes:

One does not know what it [the spectre] is, what it is presently. It is something that one does not know, precisely, and one does not know if precisely it $i s$, if it exists, if it responds to a name and corresponds to an essence. One does not know: not out of ignorance, but because this nonobject, this non-present present, this being-there of an absent or departed one no longer belongs to knowledge. (Derrida 1994, 5)

This absent-present, this paradoxical being-there of what should have departed or been expelled is something that perhaps used to but no longer belongs to a system of knowledge. As a sort of quasi-object/subject (Serres 1991), the ghost brings with it a message from a space outside of discourse and representation.

In Derrida's hauntology, spectres evolve from the impossibility of fixed 
meanings and significations. In any system of meaning, there is an ever-present corrupting and contaminating undercurrent; a spectral working that destabilises, in a more or less subterranean fashion, the order of conceptual distinctions put to work in a given context (Derrida 1994, 174). As signs consist of unstable links between signifier and signified they are subject to a constant deferral and as such 'haunted by a chain of overdetermined reading, mis-readings, slips and accretions' (Vidler 1999, 10). However, for a conceptual framework of the ghostly to be an apposite contribution to contemporary attempts to include questions of affect, embodiment and atmosphere in studies of education policy (Blackmore 2010, 2011; MacLure 2013; Staunæs 2011; Staunæs and Pors 2015; Pillow 2003), I would argue that Derrida's hauntology can be pulled a little bit out of its discursive framing in order to bring to the fore how the ghostly unfolds as affective tensions, animating forces and nagging atmospheres in the mundane everyday. In my account, the ghostly is what moves across boundaries between textual and affective and rational and emotional. As Gordon $(2008,98)$ has put it haunting is what 'prevents rational detachment, prevents wilful control, prevents the disaggregation of power and affects, motivations, blind spots, craziness, and desires.' Haunting traffics in affective registers and the ghostly is precisely the ways in which bodies all of a sudden become sensitive to suggestive and contagious atmospheres, attuned to however-small affective disturbances, and invested in reading barely-there traces of what should no longer exist.

Moreover, efforts to think about the ghostly is situated within a growing scholarly interest in the everyday (Thomson, Hall, and Jones 2010; Highmore 2011; Stewart 2007) and the belief that the quotidian may help to make sense of contemporary political cultures as even the most mundane routines may incorporate complex spatial politics and cultural meanings (Moran 2005, 2-3). Being attentive to the ghostly is an insistence that the micro-sensations felt in everyday doings have everything to do with the complexities of contemporary power relations. Indeed, it is an attempt to reckon with the fundamentally animistic mode by which worldly power is making itself felt in our everyday work life, even if that feeling is ambiguous (Gordon 2008, 202).

An interest in the ghostly can be a contribution to contemporary attempts to study policy as enacted and embedded (Ozga and Jones 2006; Adie 2014). It abandons the linear time of implementation and focuses instead on how global and national policy agendas become embedded in local traditions, histories and storytelling (Ozga, Seddon, 
and Popkewitz 2006, 8). Moreover, an interest in the ghostly is an exploration of how policy agendas are experienced in embodied and affective ways in the everyday life of educational practitioners. It tells the 'vernacular versions' of policy discourses (Lingard, Martino, and Rezai-Rashti 2013) in a particular way, namely by drawing attention to the curious ways in which the values and traditions that become silenced by particular policy initiatives may continue to linger as absent presences. It zooms in on the ambiguities and doubts felt by educational practitioners when certain knowledge, values and habits are made disposable and inadequate. A conceptual framework of the ghostly is imaginative for sure, but not fictive. It is an account of education policy as an ensemble of cultural imaginings, affective experiences, temporal collages, animated objects, marginal voices, narrative densities and eccentric traces of the presences of power (Gordon 2008, 25).

\section{Shadowing shadows}

My ghost story is based on an ethnographic study that includes interviews, observations, and shadowing as well as documents in a large Danish local Government and its 36 schools. The study focuses on how municipal chief executives and head teachers navigate between a new policy landscape formulated by national and local governments on the one hand and the professional values and traditions of their local schools and teachers on the other. I began by collecting all the documents that constitute the policy agenda of strengthening the assessment culture of the Danish public school. Besides Local Government Denmark, these include documents from the Danish Ministry of Education and OECD from 2004-2013. Some of these documents are formal policies, political statements, and background material of policy initiatives, and some are quite detailed and concrete descriptions of how head teachers can improve themselves, as well as best practice examples of schools and teachers that have successfully implemented new assessment systems. Moreover, for a period of 15 months, I followed a municipal chief executive as she moved back and forth across boundaries between the municipal bureaucracy and its public schools, primarily on days when she had meetings, seminars, and other doings central to her work of implementing a new assessment system and supervising head teachers. The data amounted to 27 days of observations and 17 interviews with other municipal chief executives, consultants and head teachers. All the citations that appear in this article have been recorded on tape and transcribed. 
Combining the document study with shadowing and observations allowed me to study both the policy world (Shore, Wright, and Peró 2011) with its normative expectations to head teachers and particular narrative orderings of the past, present and future as well as how head teachers relate to and make sense of this (for discussions of how documents contribute to the world making of organizations see Heimer 2006; Riles 2006). Moving back and forth between the document study and the shadowing allowed me to alternate panoramic views of grand institutional narratives and extreme close ups showing minor disruptions and different enactments of such narratives.

As O'Doherty et al $(2013,1432)$ have argued shadowy realities do not 'simply await their discovery, but require openness and retuning of the scholarly apparatus that allows these spaces to rise above the horizon of social invisibility.' Although the ghostly has a shape, an electric empiricity, the evidence may sometimes be barely visible (Gordon 2008, 51). In the following, by way of a minor displacing of the ethnographic concept of shadowing, I develop my methodological strategy for shadowing the shadows of the everyday life in educational organisations.

Shadowing simply means to follow a particular person in her everyday doings as she moves around in or across organizational sites (Wolcott 2003; Gill 2011; Vetter, Fairbanks, and Ariail 2011). Even without adding much to the ways in which researchers have for many years been following educational actors, there are several reasons why shadowing is an appropriate strategy for studying ghostly matters. First, and rather obvious, to be able to notice those subtle moments where an absent-presence is felt or when something well-known and homely becomes unhomely, the researcher needs the intimate knowledge that comes with ethnographic fieldwork (Deem and Brehony 1994). Second, Czarniawska (2007, 2008) has coined the concept of shadowing as 'fieldwork on the move'. Shadowing enables one to move across domains and physical locations usually seen as separate, and thus to follow the connections and tensions between different parts and logics of an organisation (Czarniawska (2008, 1011). The technique of shadowing situated me in the places in which one is most likely to encounter ghosts; namely in borderlands between organizational sites, in-between alternative traditions of practicing and organizing where different realities collide and are negotiated (Orr 2014, 1057), in this case in the borderlands between municipality and schools. Third, the somewhat strange absent-present of a researcher trying to behave as a shadow may bring a small dose of uneasiness and uncanniness to the 
situation that can enhance the sensuous sensitivity of both an educational practitioner and her shadow. It is not difficult to envision how, in the classical studies in which shadowing was first conducted, the (non)presence of the researcher could be awkward and bewildering. Imagine entering the office of the head teacher that Wolcott (2003) shadowed. Perhaps at first you do not notice it, but the office just feels different. There is a presence of something that does not belong. Inevitably you will discover it and then it is impossible to go back to 'unnoticing.' Although you try not to, your eyes flicker and you are drawn to and affected by the silent silhouette over by the window. Do you address him too with your business with the head teacher or do you ignore his presence? The point I am trying to push is that this strange presence of a body that strives to annul its presence awakens the senses of both the shadow and the person being shadowed. Uncertainty and blushing cheeks may turn out to be a rich source of insights into the doubts and affective tensions that constitute the shadowy underworld of everyday reasoning (Czarniawska 2007, 33).

However, to sharpen the sensitivity to ghostly matters of the method of shadowing, unlike Wolcott, I had little focus on registering and categorizing assignments and tasks. To shadow shadows means instead to be sensitive to sensuous knowledge, felt meanings and affective encounters. As Gordon has eloquently put it, ghostly research is 'a passion of what is at stake' (Gordon 2008, 203). This means that ghostly research is about tuning oneself into all the visceral pinches of affects and anxiety in the studied social settings (Beyes and Steyaert 2013,1448). The analytical focus is on how educational practitioners encounter and tackle with lingering presences of something that should be long gone. Shadowing shadows is about encouraging people to tell stories and enter the echoes, perplexities and emotional doubts they live with (Lohmann and Steyaert 2006, 77).

Both my reading of documents and the shadowing can be characterized as an attention to the events, situations, statements and outbreaks of intensity that may at first appear small, obvious, marginal or unimportant, and, later allowing the analysis to function as a sort of rectifier of the uncertainty, uneasiness and anxiety they are imbued with. Ghostly research practices what Lohmann and Steyart (2006, 83) have called 'heterogeneous engineering' that is producing an assemblage of bits of trivial sayings, pauses and silences, minor confessions when being given a lift to the station by an informant, as well as passages in formal policies and law briefings with grand pathos. 
Ghostly research dares to know by partaking the empirical data with a taste for the inscrutable nature of things and by believing in the cumulative effects of telling details (Holt and den Hond 2013).

I have moulded the empirical data into two analyses. First, I hunt the ghosts that lurk in the fissures between the new and the old in the policies promoting a new culture of assessment. My reading strategy was to follow how the political ambitions of transforming schools into more efficiently managed and more systematically selfassessing organisations was crafted into a specific story-line consisting of specific pasts, presents and futures (Boje, 1991, p. 106). I pursued how this narrative conveyed a number of different distinctions between desirable and undesirable practices and how these distinctions were sought sustained and how, at particular points, they seemed to collapse. I tuned into all the moments of uneasy intertwinements of pasts and projected futures: The struggles to repress or represent the past in specific ways so that it supports gleaming futures, and, the moments in which the apparent order of a better future becomes colonized by heterogeneous and contradictory elements (Degen and Hetherington 2001). Thereby, I strived to show how policy papers do not only communicate the vision of improvement, but also the fear that the strived for future is threatened by disturbing obduracies. Second, I bring the reader to a specific event at which head teachers share with each other their encounters and worries about the hidden, silent and disturbing forces they experience their organizations haunted by. I have assembled three small exchanges of words in which head teachers evoke sensuous knowledge or uncanny experiences to describe conditions of management, or in which they suggest the impact of hidden forces, affective intensities and shadowy realities.

\section{The ghostly workings of a policy narrative}

The policy initiative A Culture of Evaluation - a New Danish School Tradition launched by LGDK as a response to criticism voiced by national and international reports established two areas of needed development. The first was more and better management (LGDK 2005a, 3; Municipal Chief Executives of Children and Youth Policy 2005, 17). Public schools needed to escape a past in which head teachers did not see themselves as municipal managers, but rather as teachers who happened to be placed in the principal's office and therefore had to perform some administrative tasks (LGDK 2008a, 2008b). And the second was a lack of assessments that resulted in weak 
connections between the overall objective of schools and the "many spontaneous quickfix activities characterizing the school today' (LGDK 2005a, 3, 2005b; Møller 1997, 24). The needed change would 'require a persistent interest at the schools and in the municipalities in working systematically with results, assessment, reflection and followup' (LGDK 2005a, 3, 2009a). It was stated that all school actors needed to agree upon the fact 'that there is too much "we think" in the school' and establish firm connections between formal policies, and all the activities going on in the everyday life of the school' (LGDK 2005a, 3, 2005b). The pressing issue here was that teachers needed to change their practices so that they would be more aligned with overall goals, more based on the newest didactical knowledge and more systematically the object of (self-) assessment (Municipal Chief Executives of Children and Youth Policy 2005, 6; LGDK 2010b, 2, 7). Moreover, an improved school was described as a transparent school. The quality of the teaching was argued to be a matter of the way in which teaching activities were made visible outside the here and now of classroom teaching (LGDK 2005a, 3, 14, 2010b, 2002, 1998, 4). It was argued that this included the termination of the so-called 'oral culture' of the public schools and the initiation of efforts to assess and document activities and results (LGDK 2005a, 3, 2009b).

The narrative of a needed change emerging in Danish education policy sets up a somewhat conventional tension between a desired future and an inadequate past. The future to be achieved consists of strong managers not afraid of using the management competence they have been given (LGDK 2010b, 6, 2009a, 9), of firm connections between goals and everyday activities, and of efforts to make teaching activities visible and produce formal self-assessments. The past that must be abandoned includes a culture of equality in which head teachers do not interfere in teachers' affairs (LGDK 2005a, 13-16), so-called 'non-decision areas' argued to be 'ruled by a complete indifference to whether decisions are carried through or not' (Windinge 1996, 33; LGDK, 2010a) and non-transparent teaching activities behind closed doors with no written documentation. However, there is also a lot going on in between these two images of a public school; first and foremost, a pressing concern that although the wanted change can be described as desirable, self-evident and necessary, teachers may not see it this way. The OECD report that initially framed the problem of a lack of assessments, called for a new 'culture of assessment.' This term indicates that what was 
demanded was not only more performance measurements, but also a cultural change in the professional identity and everyday actions and attitudes of teachers:

Real change occurs in the class room when teachers acknowledge that change is necessary and of their own wish to work towards it. More strict attempts to force teachers to change behaviour will often be cleverly undermined or met with direct resistance. As most professionals, teachers react to hostile critique by building defences from where they can resist change. (OECD 2004, 130-131)

And LGDK $(2005,9)$ concurs: 'An assessment culture can only become real if the stakeholders of the school are willing to change their habits. ... The willingness will only emerge if teachers genuinely discover that this is important.' The policy narrative of a needed change conveys a worry that teachers are difficult to change. It carries with it a sneaky feeling that much too much is going on within the walls of a school that escapes management. Indeed, the narrative is full of quite lively fantasies about a range of modes of being that seem to represent the difficulty of managing in a borderland between the old and the new. As a first step in the change process, local government executives and head teachers are encouraged to identify 'which hidden values, attitudes and social conventions that in reality control the activities of the school?' (LGDK 2005a, 4, 1998, 65) These are depicted as elusive and tacit, and the task of head teachers is to identify and deport them by asking teachers to verbalise them:

Silent habits shall therefore be put into words. It is strictly necessary linguistically to relate oneself to new ideas - for instance the notion of evaluation - and to be conscious of one's choices if habits or behaviour are to be changed. (LGDK 2005a, 4)

In the fissures between the new and old, policy papers depict a seething presence of former modes of existence. In the process of changing the school to a more systematically self-assessing organisation, the tacit comes to represent that which should belong to the past, but lingers in the margins. Also, the unconscious inhabits these margins:

Habits are patterns of action that are meaningful for an actor. However, this meaningfulness is often unconscious. There is a lot of "usualness" and "silence" in habits. Habits ... stagnate within certain traditionally delimited frames. To change habits, it is strictly necessary that the individual human being makes an effort to become conscious of his own habits. (LGDK 2005a, 4) 
In the midst of efforts to change schools, the tacit and the unconscious are not just behaving nicely as a safe depiction of a past the school is leaving behind. Rather, the silent and unconscious become a disturbing presence with their own repetitive life outside the attempts to produce change. Policy papers create a social world in which a seething presence of unruly forces resides just below the surface of verbalised and conscious reality.

Furthermore, a blind spectre is conjured up: 'Blind action in education is called practisism ... Blind action is completely controlled by practical circumstances' (theoretical statement from an individual school in the municipality). Blindness emerges as troublesome because, by refusing to see, blind action is believed to be unreachable by managerial attempts to order and only controllable by unpredictable and coincidental eireumstances. As Gordon (2008, 16-18) reminds us, the ghostly has to do with intimate relations between visibility and a 'complex system of permission and prohibition'. The narrative of a changed public school portrays a world in which everything can be made visible and, if made visible, can be consumed and utilised as official self-descriptions, documentation, and so on, with the rationale that visibility equals quality. And yet, there is a seething presence of blindness that draws attention to the limits of this rationale. That which refuses to see becomes unreliable, not to be trusted and ruled by different forces than the ones policy papers aim to evoke.

Although policy papers describe and promote appropriate actions for producing a more systematic and well-managed public school, it seems there is a corrupting and contaminating undercurrent. Even though all the uncertainty of teachers' blind practices and spontaneous quick-fixes is repeatedly positioned as a strange otherness from the past, the policy papers cannot help but remain occupied with this uncertainty. Thus, OECD reports and policy papers from LGDK do not only convey the cheerful message of a better performing, modernized public school, but also diffuse a fear that schools are ruled by shadows of silent, unconscious and blind modes of existence.

\section{Relating to the ghostly}

One watches for the signals, the tables that turn, the dishes that move. Is it going to answer? (Derrida, 1994, 124)

I will now present three exchanges of words occurring at a seminar arranged by the municipality for its 36 school head teachers in the assembly hall of one of the schools. I 
will explore how school the head teachers navigate in temporal borderlands between pasts, presents and futures, and organizational borderlands between the municipal policy and the everyday school management. How do they relate to that which is not part of the better, transformed school, but yet, as we shall see, is talked about all the time? How do they seek to determine whether or not the ghost exists and how powerful its ability to disturb the present is?

On the day of the seminar, I arrive early at the school together with the municipal executive chief I shadow, Hannah, who has been so kind as to pick me up at the train station. She has planned a programme for the school head teachers, starting with a short lecture given by a professor in education from the regional university, followed by a set of questions that the school head teachers are to discuss in smaller groups. Everything is ready in the assembly hall when we arrive. Her staff has prepared a PC, a projector, and a white screen for the professor's power point presentation, and they have set up seven circular tables with chairs around them. Soon, head teachers of different gender and age begin to fill the room, greet each other and chat a bit and then eventually find seats. I - more or less randomly - chose three tables on which, after having asked the head teachers around the table for permission, I place the tape recorders I have brought, and, then I find a seat at a fourth table.

The municipality arranges a seminar similar to this more or less once a month in order to facilitate the sharing of knowledge and experiences between the head teachers, who, as Hannah has explained to me, only have themselves to consult in their everyday work and may feel a bit alone at their individual schools. In a previous interview, she told me that if they as a municipality are to be successful in transforming the schools into systematically self-assessing organizations, then it is extremely important that they pay the head teachers adequate respect. After all, they are the ones who have to defend this transformation when confronted with large groups of sceptical teachers. 'You have to be very gentle,' she stated, 'mind your words. If they get just the slightest feeling that they are being talked down to. You need to display humility and servility. They do all the difficult work out there.' A pilot study in a different municipality has given me an idea of what this difficult work consists of. There, a municipal consultant said in an interview:

The expectations of the school head teachers have increased dramatically. They need to take control and actually manage their staff of teachers. Many of them are former teachers or deputy head teachers and they are 
not up for it. They have not been taught how to develop the professionalism of teachers. They are dead scared.

Thus, I am aware that the borderlands between new policies and the everyday life of the school can be charged with affective electricity. Navigating in this borderland is not only difficult for the head teachers, but also for the municipal executives and consultants. As Hannah puts it, when new municipal staff is to meet the head teachers for the first time, she always says, partly joking, partly being serious: 'Now you will be thrown to the wolves'.

After the presentation of the professor, the first question to be discussed around the tables appears on the large screen. It reads: 'Is it a problem if the teachers of a school do not share the same understanding of what good teaching is?' After a bit of 'well', 'yeah', and 'sometimes', the following exchange of words occurs at one table.

'It has something to do with history, going all the way back to the way in which teacher training colleges used to work. There you could not talk about what good teaching is because [in an ironic tone:] that can't be measured - it was not even a topic of discussion. Oh no. It is oh so subjective and contextual. [Normal voice:] It has something to do with how it has always been. It also has a lot to do with how strong the teacher union used to be.'

'I heard someone put it quite neatly: Everybody wants improvement, but no one wants change.'

'Yes, yes.'

'That's true.'

'It is completely true.'

'I would even say that the teacher culture nurtures hostility towards theory. They think external forces are evil and want to harm them. So they better shut the door to the classroom. It isn't easy to break with your own tradition and practice. Not when you're alone. When they work together in teams of two or three, I think it's easier.'

'And our culture and habits - the so-called freedom of methods - that is a dangerous phenomenon!'

In the conversation, a ghost of the past is identified as ubiquitous remnants of outmoded habits (Edensor, 2008, 315). Specifically, a ghost associated with teacher training colleges, the former influence of the union and a general idea that what good teaching is can only be decided by individual teachers in specific situations. We learn that the ghost is most likely to emerge when teachers are alone behind closed doors. And that it can be kept at a distance when teachers work together. Head teachers seem concerned that that which is outdated is still in use or remains an enduring fixture around which the routines of teachers take place. The ghost that they identify is an uncanny creature in so far as it is a strange configuration of familiar yet disturbing elements. They evoke a well-known 
and shared history of bygone days at the teacher training colleges (all head teachers are trained as teachers) and key concepts in the teaching profession, such as the freedom of methods. Yet, these familiar elements are depicted as inappropriate in the contemporary school and even as a 'dangerous phenomenon'. In Freud's famous account, the uncanny is precisely a feeling of unease when something familiar becomes strange and unfamiliar (see Beyes and Steyaert 2013, 1448). Head teachers seem very much at home when remembering debates in college or the former influence of the teacher's union. And yet, these elements are depicted as nurturing hostility. The uneasiness the elements bring about seems to arise from the way in which they are simultaneously foreign and intimately part of the domain that renders them foreign (Wigley 1995, 108).

In Freud's description, uncanny experiences are also described as 'doubts whether an apparently animate being is really alive; or conversely, whether a lifeless object might be in fact animate' (Freud 1919, 226). As the following exchange of words show, school head teachers around the table try to negotiate whether or not the ghost is there and how powerful it is. Is it a long-gone past or is it lurking in every corner of the school, behind every door to every classroom? Some of the younger head teachers argue that the ghost does not inhabit their particular schools because all their teachers are young and believe in new and other professional values. They argue that their staff is not resistant to management but actually request it, and that the ghosts disappeared with the declining influence of the teacher's union. But these arguments are challenged:

\footnotetext{
'Some teachers $d o$ take in new theories and act accordingly.'

'So I would say. But perhaps it is more random and private.'

'But remember; when facing you, they say things to make a good impression - it is like an exam. They take on a role that can be difficult for us to see through.'

'With new initiatives, I have often experienced that, at first, teachers are very interested. They want to participate. Although everybody was at first applauding, then after a while there was almost nobody [pauses]. Perhaps these things just take a very long time to digest.'
}

The ability of the third comment to re-evoke the ghost that the first statement buries may stem from the way in which who is observing who is turned around. As Derrida phrases it, the spectral is about how

... someone other looks at us, we feel ourselves being looked at by it, outside of any synchrony, even before and beyond any look on our part, according to an absolute anteriority and asymmetry, according to an absolutely unmasterable disproportion. (Derrida 1994, 5-6) 
With a policy agenda of systematic assessment, management is supposed to be about head teachers observing and assessing teachers (LGDK 2005a, 13-16), but heads experience their ability to see as being obstructed by the false face teachers put on. An uncanny feeling arises that perhaps it is teachers who observe heads and secretly (or unconsciously) decide not to follow them.

It seems the resistance becomes disturbing precisely because of their contested ontological status: They are a sort of absent-presences that disappears when you confront them directly, but yet are never completely gone. The heads do not know precisely what name this experience can be given and, thus, there is no formula for how to relate to it, let alone control it by giving it a name. Head teachers are confronted with a sense of fragility in a world of shadows that escape any clear boundary between present and absent that might have made them possible to relate to.

The difficulty of relating to a seething presence of unwillingness to act in accordance with what has been agreed upon in meetings is elaborated in the following exchange of words:

'For instance, with the example of portfolios [an agreed upon assessment technology] - I can really recognize that - because will there be loyalty toward the decisions made in the organizational collective? Or will one just make a private interpretation and find a good reason - freedom of methods or whatever - that this decision is good, but it doesn't apply to me in this particular situation. As a manager, I don't know how to relate to that. It isn't a deliberately subversive operation against what is collectively decided.'

'But it's this repetition of some unchangeable pre-understandings and rituals.'

'It's true. $80 \%$ of human beings are afraid of change.'

'But also considering what the presentation [by the professor] was also about, namely how our conditions of managing are shaped by the political climate right now and the direction our politicians want our education system to take. Actually, when I think about all the consequences this will have for our children in the future, it sends a cold shiver down my spine.' (Emphasis added)

Here, the dangerousness of private interpretations seems to arise from the fact that they do not just affirm or reject managerial expectations. If the private interpretations were outspoken and considered, head teachers could address them as resistance. The ghostly is not simply an other or alterity as such (Gordon 2008, 183). Private interpretations, unconscious habits and blind practices all escape the preference for clear markings of the policy narrative, such as distinctions between visible and invisible or between 
working in accordance or not in accordance with goals and common agreements. The ghostly presence head teachers experience is not simply deliberate resistance, but rather an uncanny agency with its own autonomous, repetitive life.

From this location, in between the dichotomies of a certain policy agenda, the seething presence of the silent forces trigger, at least in one of the head teachers, a reflection upon her navigation in a liminal and indeterminate grey zone, where the boundary between desired behaviour and misconduct may not be as clear as the policy papers argue. The encounter with the ghostly come to resonate affectively with at least one of the heads' own doubts and hesitation about the policy changes she is meant to implement. Thinking about the future from that particular moment of the conversation and from that particular moment in the larger policy process and envisioning what may be lost in that future prompts a bodily sensation. On the one hand, the statement, 'It sends a cold shiver down my spine' indicates a clear and unmistakeable affective experience. Yet, on the other hand it is also fleeting and ambiguous. From a position enmeshed in normative expectations, temporal collages and affective densities, the head expresses a clear, if undetermined concern for the route education is taking.

In the sense that the purpose of the seminar is to create an occasion in which head teachers can share knowledge and experiences and thus optimise their ability to move their schools away from a certain past, head teachers come together to exorcise a ghost. And yet, when someone proclaims its death, they repeatedly testify to its lingering presence and thereby breathe life into it. Although the aim of the seminar is to nurture and support the fragile emergence of a reformed school, the meetings also seem to function as a rectifier of anxiety, uncertainty and noise. The ghostly presences are difficult to relate to since they cannot be directly confronted. The ghost is an elusive force with a repetitive, autonomous life just below the surface of impression management, and in the near future when, alone behind closed doors, teachers are not doing what they promised. The ghost escapes dichotomies and reverses directions of observation. Thereby, the ghost draws attention to the very conditions of management in temporal and organizational borderlands, not only by revealing managers as fragile and dependent upon forces they do not control, but also by evoking an sensuous awareness that distinctions between light and dark are political, contingent and even precarious. 


\section{Conclusion: What is about to be lost}

This article has sought to exhibit how a theory of the ghostly may allow for a dwelling in rather conventional policy narratives and mundane conversations to discover how the complexities of contemporary power make themselves felt. With a point of departure in a study of the political ambitions of improving the management and the manageability of the Danish public school, I have explored the curious ways in which educational organisations remain affected by the pasts that become unwanted en route to a better performing version of themselves. Whereas policy narratives of change often work by assembling and joining a number of elements such as inadequate pasts or promising futures, ghost stories leads us to what is gaping, detouring, and haunting in change processes. This includes how attempts to terminate particular pasts may also revitalise them in unexpected ways. In the case of Danish education, the policy narrative of a necessary change do not just convey the vision of a better performing and bettermanaged school, but also conjure up ghostly imaginaries of blind, silent and unconscious shadows that make schools difficult to manage, change and improve. Although, the studied policy is intended to strengthen management, it may also undermine it by populating the school with unruly, invisible forces resistant to management. Thus, attending to ghostly matters may teach us something about, not just the fissures between shiny futures and inadequate pasts, but also the entanglements of hopes and fears in education policy: How new political agendas thrive on, but may also be asphyxiated by their own vivid imagination of obdurate habits and lurking resistance. Even if the conviction remains that better management is a direct path towards better performing public schools (see Blackmore and Thomson 2004), perhaps times of great policy changes also reveal that political omnipotence and impotence are more intimately connected than often assumed.

In the analysis of three excerpts from a seminar for head teachers, I showed how when seated around circular tables to reflect upon how to exorcize the left overs of old traditions and a too strong influence of teacher collectives, head teachers share their concerns and ghostly experiences. The ghosts that they have encountered are uncanny creatures, simultaneously foreign and intimately part of the domain that renders them foreign. 'Blind practice' or 'private interpretations' are difficult to relate to for head teachers since they do not simply affirm or reject policy initiatives and managerial 
communication, but escapes the dichotomies underpinning the rules of what presently counts as quality in education (i.e. visible/invisible; connected to goals/ not connected to goals). Moreover, the testimonial, 'It sends a cold shiver down my spine', reveals that ghostly experiences also prompt reflection upon what it means to manage education in times of certain political convictions. In recent years, head teachers have found their pedagogical values projected into broader political agendas so that the meaning and value of education are not only constantly contested, but also made a means to other ends such as national competitiveness in a globalized economy (Jessop 2002; Ball 2009; Pedersen 2010). Haunting has at its core a contest over the future, over what is to come next (Gordon 2011). The ghostly evokes doubts and ambivalence in at least one head teacher, making her wonder about the future consequences for children of the change she is supposed to produce. In Gordon's $(1999,183)$ account, ghostly presences are not only related to mourning over lost pasts, but also over lost futures. Head teacher may worry about what the school could have become in the future if some of the professional values repressed by the present eagerness to transform could have been preserved and carried into the future. This also means that the ghostly is not simply a passive, dystopian grieving over a lost past, but rather the insidious feeling that something important is about to be lost. Elusive traces of out-dated habits and traditions seem to resonance with the studied head teachers' own doubt and ambiguous feelings towards the change they are meant to produce. Through ghostly sensations policy changes are also experienced as a something-to-be-done, a need for counter-action, however vaguely felt.

With this study, I have sought to contribute to the growing body of literature that engages with the question of how policy is enacted and embedded in particular sites. In Lingard and Sellar's (2013) work, they distinguish between two ways in which global policy regimes are enacted locally. Local actors may either fear the techniques of government and management associated with an audit culture, where performance of teachers and school leaders is constantly monitored against publically reportable criteria and in turn produces detrimental effects such as i.e. lowering staff morale or narrowing curriculum to teaching to the test. Or, they may perform different sorts of 'resignification' understood as a mode of agency for thinking otherwise to manoeuvre around performance regimes and mitigate these negative effects. Also Niesche (2013), and, similarly, Gowlett (2013) draws attention to the ways in which local actors resist 
policy with different sorts of resignification thereby shifting the meaning and finding other unforeseen possibilities of circumventing the policy intentions. Other scholars such as Singh, Heimans and Glasswell (2014) go even further and portray educational practitioners as full of hope and resistance, of great resourcefulness, courage and willingness to not just confront the pressure to perform, but actively engage with a completely different set of ideas about what schooling might be about.

Similarly, this study has testified to the fact that global regimes of accountability have multiple and diverse effects. However, the studied head teachers are difficult to categorise as either repressed or resisting educational subjects. Rather, in this particular case, the effects of an accountability policy are ambivalent feelings, doubt and not knowing precisely how teachers actually relate and react to new policy initiatives. The intensities and power relations produced by new policies seem to remain indefinite even as they effect (see Anderson 2009, 78). In their everyday doings, the head teachers are not, it seems, only concerned with being subjected to performance measurement and enrolled in accountability regimes; they also struggle to live with and tackle the seething presences that reminds them of the equally frightening failure and success of recent policy developments. The aim of this article has been to grasp how small, almost not uttered concerns have everything to do with the political regimes educational organisations are embedded in. An interest in the ghostly takes the scholar to the quotidian to learn about the reality of contemporary policy discourses. It is an attempt to think through occurrences and experiences, not above them. It is similar to what Highmore $(2011,20)$ has called a 'political aesthetic inquiry into the ordinary', that is to 'understand the way that the opaque and oblique machinations of global politics (economic, environmental and cultural) punctuate and syncopate the rhythms of ordinary life.' Approaching local instantiations of policy as a case of haunting pulls us towards learning what it means to be connected to what has or is about to disappear, even in times when national moods favour fast improvement and adjustment to global demands. It makes us interested in how educational practitioners live with the shadows of our society and the subjects it inclines us to become.

\section{References}

Anderson, B. 2009. “Affective Atmospheres.” Emotion, Space and Society 2 (2): 77-81. 
Beyes, T., and C. Steyaert. 2013. "Strangely familiar: The uncanny and unsiting organizational analysis." Organization Studies 34 (10): 1445-1465.

Ball, S. J. 2003. "Professionalism, Managerialism and Performativity." In Professional Development and Educational Change - what does it mean to be a professional in education?, edited by L. Moos, and J. Krejsler, 23-44. Copenhagen: Danish University of Education Press.

Ball, S. J. 2006. Education Policy and Social Class: Selected Works. London: Routledge.

Ball, S. J. 2009. Privatising Education, Privatising Education Policy, Privatising Educational Research: Network Governance and the 'Competition State.' Journal of Education Policy 24(1): 83-99,

Ball, S., M. Maguire, and A. Braun. 2012. How Schools Do Policy: Policy Enactments in Secondary Schools. New York: Routledge.

Blackman, L. 2008. “Is happiness contagious?” New Formations 63: 15-32.

Blackmore, J. 2010. "Preparing leaders to work with emotions in culturally diverse educational communities.” Journal of Educational Administration 48 (5): 642-658.

Blackmore, J. 2011. " 'Lost in translation? Emotional intelligence, affective economies, leadership and organizational change." Journal of Educational Administration and History 43 (3): 207-225.

Blackmore, J. and P. Thomson. 2004. "Just 'good and bad news'? Disciplinary imaginaries of head teachers in Australian and English print media." Journal of Education Policy 19 (3): 301-320.

Boje, D. 1991. The storytelling organization: A story of story performance in an officesupply firm. Administrative Science Quarterly, 36: 106-126.

Cho, G. M. 2007. "Voices from the Teum: Synesthetic Trauma and the Ghosts of the Korean Diaspora." In The Affective Turn: Theorizing the Social, edited by P. T. Clough, and J. Halley, 151-169. Duke University Press.

Cho, G. M. 2008. Haunting the Korean Diaspora: Shame, Secrecy and the Forgotten War. Minneapolis, MN: University of Minnesota Press.

Clatter, R. 2002. "Governance, Autonomy and Accountability in Education." In The Principles and Practice of Educational Management, edited by T. Bush, and L. Bell, 44-59. London: Paul Chapman.

Coddington, K. S. 2011. "Spectral geographies: haunting and everyday state practices in colonial and present-day Alaska." Social and Cultural Geography 12 (7): 743-756.

Coffield, F. 2012. "Why the McKinsey Reports will not Improve School Systems." Journal of Education Policy 27 (1): 131-149. 
Czarniawska, B. 2007. Shadowing and other Techniques for Doing Fieldwork in Modern Societies. Malmo: Liber.

Czarniawska, B. 2008. "Organizing: how to study it and how to write about it." Qualitative Research in Organizations and Management: An International Journal 3 (1): 4-20.

Danish Institute of Evaluation. 2006. Skoleledelse i folkeskolen. [Management in the public school] Copenhagen: Danish Institute of Evaluation.

Danish Institute of Evaluation. 2004. Lфbende evaluering af elevernes udbytte af undervisningen i folkeskolen. [Running assessment of pupils' profit from teaching in the public school] Copenhagen: Danish Institute of Evaluation.

Danish Ministry of Education. 2007. Improving School Leadership - En national baggrundsrapport. [Improving school Leadership - a national report] Conducted by Pluss Leadership A/S and Jan Molin. www.uvm.dk.

De Certeau, M. 1984. The Practice of Everyday Life. Berkeley: University of California Press.

Degen, M., and K. Hetherington. 2001. "Guest editorial: Hauntings.” Space and Culture $1(11 / 12): 1-6$.

Deem, R., and K. Brehony. 1994. "Why didn't you use a survey so you could generalize your findings?: Methodological issues in a multiple site case study of school governing bodies after the 1988 Education Reform Act." In Researching education policy: ethical and methodological issues, edited by D. Halpin, and B. Troyna, 154-169. Psychology Press.

Derrida, J. 1994. Specters of Marx: The State of the Debt, the Work of Mourning and the new International. New York and London: Routledge.

Derrida, J. 1999. "Marx and sons." In Ghostly demarcations: A symposium on Jacques Derrida's Specters of Marx, edited by M. Sprinker, 213-269. London: Verso.

Dudley, S. 2006. Walking ghosts: Murder and Guerrilla Politics in Colombia. New York: Routledge.

Edensor, T. 2008. "Mundane hauntings: Commuting through the phantasmagoric working-class spaces of Manchester, England.” Cultural Geographies 15 (3): 313-333.

Edensor, T. 2001. "Haunting in the ruins: matter and immateriality." Space and Culture, $1(11 / 12): 42-51$.

Freud, S. 1910. The uncanny. In The Standard Edition of the Complete Works of Sigmund Freud, vol. 14. London: Hogarth Press and the Institute of Psycho-analysis. 
Gill, R. 2011. "The shadow in organizational ethnography: moving beyond shadowing to spectacting." Qualitative Research in Organizations and Management: An International Journal 6 (2): 115-133.

Gordon, A. F. 1999. "Debate Making Pictures of Ghosts: The art of Gary Simmons." Journal for the Study of Race, Nation and Culture 5 (1): 89-124.

Gordon, A. F. 2008. Ghostly matters: Haunting and the Sociological Imagination. Minneapolis: University of Minnesota Press.

Gowlett, C. 2013. "Queer(y)ing New Schooling Accountabilities through My School: Using Butlerian Tools to Think Differently about Policy Performativity." Educational Philosophy and Theory 47 (2): 159-172.

Grek, S. 2009. "Governing by numbers: the PISA 'effect' in Europe.” Journal of Educational Policy 24 (1): 23-37.

Heimer, C. A. 2006. Conceiving Children: how documents Support Case versus Biographical Analyses. In Documents. Artifacts of modern knowledge, edited by A. Riles, 95-126. Ann Arbor: University of Michigan Press.

Hetherington, K. 2004. "Secondhandedness: Consumption, Disposal and Absent Presence." Environment and Planning d: Society and Space 22 (1): 157-73.

Highmore, B. 2011. Ordinary Lives. Studies in the everyday. London: Routledge.

Holloway, J. 2006. "Enchanted spaces: The Séance, Affect and Geographies of Religion." Annals of the Association of American Geographers 96 (1): 182-187.

Jessop, B. 2002. The Future of the Capitalist State. Cambridge: Polity.

Kenway, J. 2008. The ghosts of the school curriculum: Past, present and future. The Australian Educational Researcher, 35 (2): 1-13.

Kenway, J., E. Bullen, J. Fahey, with S. Robb. 2006. Haunting the Knowledge Economy. London: Routledge.

Lawn, M., and J. Furlong. 2009. "The Disciplines of Education in the UK: Between the Ghost and the Shadow." Oxford Review of Education 35 (5): 541-552.

Lawn, M., and S. Grek. 2012. Europeanizing Education: Governing a new Policy Space. Symposium Books Ltd.

Lingard, B., W. Martino, and R.-R. Goli. 2013. "Testing regimes, accountabilities and education policy: commensurate global and national developments." Journal of Education Policy 28 (5): 539-556.

Lingard, B., and S. Sellar. 2013. "“Catalyst Data': Perverse Systemic Effects of Audit and Accountability in Australian Schooling." Journal of Education Policy 28 (5): 634656. 
Local Government, Denmark. 1998. Metodekommode. Resultatvurdering i folkeskolen (A chest full of methods. Assessing results in the public school). Copenhagen. Municipal Information.

Local Government, Denmark. 2002. Alle børn skal laere mere [All children must learn more]. Copenhagen: LGDK.

Local Government, Denmark. 2005a. Evalueringskultur. En ny skoletradition. [A culture of evaluation. A new school tradition] Copenhagen: LGDK.

Local Government, Denmark. 2005b. Leder. [Editorial] In the municipal newsmagazine, Danish Municipalities, 06.10.2005.

Local Government, Denmark. 2008a. Kommunerne styrer mod god kvalitet og $h \phi j$ faglighed i folkeskolen. [Municipalities steer towards high quality and educational standards in the public school]Det fælleskommunale kvalitetsprojekt. [The national quality project] Copenhagen: LGDK

Local Government, Denmark. 2008b. Resultater fra et falleskommunalt kvalitetsprojekt. God kvalitet og høj faglighed i folkeskolen. [Results from a joint municipal project. Good quality and high educational standards in the public school] Det fælleskommunale kvalitetsprojekt. [The national quality project] Copenhagen: LGDK.

Local Government, Denmark. 2009a. Kvalitet i kommunerne - resultater fra kvalitetsprojektet. [Quality in the municipalities - results from a quality project]. Copenhagen: LGDK.

Local Government, Denmark. 2009b. Partnerskab om folkeskolen. [Partnership for the public school] Copenhagen: LGDK.

Local Government, Denmark. 2010a. Folkeskolen - Et stort kommunalpolitisk ansvar. [The public school - a great responsibility of local politics]. News from the board of $L G D K$, Special Issue, January 2010.

Local Government, Denmark. 2010b. Alle elever skal have stфrre udbytte af undervisningen [All pupils must gain more from teaching] 22 ${ }^{\text {nd }}$ of January 2010. Copenhagen: LGDK.

Lohmann, P., and C. Steyaert. 2006. "In the meantime: Vitalism, affects and metamorphosis in organizational change.” In M. Fuglsang and B. M. Sorensen (Eds.), Deleuze and the social (pp. 77-95). Edinburgh: Edinburgh University Press.

MacLure, M. 2013. "Researching without representation? Language and materiality in post-qualitative methodology." International Journal of Qualitative Studies in Education 26 (6): 658-667.

Maddern, J.F. 2008. "Spectres of Migration and the Ghosts of Ellis Island." Cultural Geographies 15 (3): 359- 381. 
Maddern, J.F., and P. Adey. 2008. "Editorial: Spectro-geographies." Cultural Geographies, 15 (3): 291-295.

McCormack, D. P. 2010. "Remotely sensing affective afterlives: The spectral geographies of material remains." Annals of the Association of American Geographers 100 (3): 640-654.

McGhee, M.W., and S.W. Nelson. 2005. "Sacrificing Leaders, Villainizing Leadership: how educational accountability policies impair school leadership." Phi Delta Kappa, 86 (5): 367-372.

Miles, M. 2001. "Ghostly pasts, spectral futures.” Space and Culture 1 (11/12): 106122.

Moran, J. 2005. Reading the everyday. Oxon: Routledge.

Municipal Chief Executives of Children and Youth Policy. 2005. En folkeskole $i$ verdensklasse. [A world class public school] www.bkchefer.dk

Møller, P. 1997. Måling i folkeskolen bør være en naurlig sag. [Assessment in the public school should be a natural agenda] Danish Municipalities 24: 24-25.

Niesche, R. 2013.“Governmentality and My School: School Principals in Societies of Control." Educational Philosophy and Theory, 47 (2), 133-145.

O’Doherty, D., C. De Cock, A. Rehn, and K.L. Ashcraft. 2013. New sites/sights: Exploring the white spaces of organization. Organization Studies 34 (10): 1427-1444.

OECD 2004. OECD-rapport om grundskolen i Danmark - 2004. [OECD-report on the primary school in Denmark] Conducted by Mortimore, P., David-Evans, M., Laukkanen, R., Valijarvi, J. The Agency of Education theme series no. 5.

OECD. 2008. Improving School Leadership, Education and Training Policy. Teaching and Learning International Survey. Conducted by B. Pont, D. Nusche, and H. Moorman. OECD.

Orr, K. 2014. “Local Government Chief Executives' Everyday Hauntings: Towards a Theory of Organizational Ghosts.” Organization Studies 35 (7): 1041-1061.

Pedersen, O. K. 2010. "Institutional Competitiveness: How Nations Came to Compete." In The Oxford Handbook of Comparative Institutional Analysis, edited by O. K. Pedersen, G. Morgan, J. L. Campbell, C. Crouch, and R. Whitley, 625-658. Oxford: Oxford University Press.

Pile, S. 2005. Real Cities: Modernity, Space and the Phantasmagorias of City Life. London: Sage.

Pillow, W. 2003. “'Bodies are dangerous': using feminist genealogy as policy studies methodology." Journal of Education Policy 18 (2): 145-159. 
Riles, A. Ed. 2006. Documents. Artifacts of modern knowledge. Ann Arbor: University of Michigan Press.

Sellar, S., and B. Lingard. 2013. "The OECD and the Expansion of PISA: New Global Modes of Governance in Education." British Educational Research Journal. 40 (6): 917-936.

Serres, M. 1991. Rome: The Book of Foundations. Stanford, CA: Stanford University Press.

Shore, C., Wright, S., \& Però, D. Eds. 201. Policy worlds: Anthropology and the analysis of contemporary power. Oxford: Berghahn Books.

Singh, P, S. Heimans, and K. Glasswell. 2014. "Policy Enactment, Context and Performativity: Ontological Politics and Researching Australian National Partnership Policies." Journal of Education Policy 29 (6): 826-844.

Staunæs, D. 2011. "Governing the potentials of life itself? Interrogating the promises in affective educational leadership." Journal of educational administration and history 43 (3): 227-247.

Staunæs, D. and M. Juelskjær. 2015. "Orchestrating intensities and rhythms: How postpsychologies are assisting new educational standards and reforming subjectivities." Theory \& Psychology.

Staunæs, D., and J. G. Pors. 2015. "Thinking educational policy and management through (frictional) concepts of affects." In Education policy and contemporary theory. Implications for research, edited by M. Clarke, K. N. Gulson, and E. B. Petersen. London: Routledge.

Stewart, K. 2007. Ordinary Affects. Durham and London: Duke University Press.

Thrift, N. 2002. "Performing Culture in the New Economy." In Cultural Economy, edited by P. du Gay and M. Pryke, 201-233. London: Sage.

Thomson, P., C. Hall, and K. Jones. 2010. "Maggie's day: a small scale analysis of English education policy." Journal of Education Policy 25 (5): 639-656.

Vetter, A. M., C. Fairbanks, and M. Ariail. 2011. “'Crazyghettosmart': a Case Study in Latina Identities." International Journal of Qualitative Studies in Education 24 (2): 185-207.

Vidler, A. 1999. The Architectural Uncanny: Essays in the Modern Unhomely. Cambridge, MA: MIT Press.

Wigley, M. 1995. The Architecture of Deconstruction: Derrida's Haunt. Cambridge, MA: MIT Press. 
Walsh, P. 2006. "Narrowed horizons and the impoverishment of educational discourse: teaching, learning and performing under the new educational bureaucracies." Journal of Educational policy 21 (1): 95-117.

Webb, R., G, Vulliamy, A. Sarja ,and S. Hamalainen. 2006. “Globalization and Leadership and Management: a Comparative Analysis of Primary Schools in England and Finland." Research Papers in Education 21 (4): 407-432.

Webb, P. T. 2005. "The Anatomy of Accountability.” Journal of Education Policy 20 (2): 189-208.

Weiner, G. 2002. "Auditing Failure: Moral Competence and School Effectiveness." British Educational Research Journal 28 (6): 789-804.

Williams, J., and J. Ryan. 2000. "National Testing and the Improvement of Classroom Teaching: Can They Coexist?” British Educational Research Journal 26 (1): 49-73.

Wilson, D., B. Croxson, and A. Atkinson, A. 2006. What Gets Measured Gets Done: Headteachers' Responses to the English Secondary School Performance Management System. Policy Studies 27 (2): 153-171.

Windinge, H. 1996. Skoleudviklingens Bermuda-trekant- Et organisationssociologisk essay om skoleudvikling. [The Bermuda-triangle of school development - an organizational sociological essay about school development] Unge Padagoger, A37, $15-27$.

Wolcott, H. F. 2003. The Man in the Principal's Office. Walnut Creek, CA: Altamira Press.

Wylie, J. 2007. The Spectral Geographies of W. G. Sebald. Cultural Geographies 14 (2): 171-188. 